\title{
Cardiomyocyte-Specific Transgenic Expression of Prolyl-4-Hydroxylase Domain 3 Impairs the Myocardial Response to Ischemia
}

\author{
Anke Zieseniss ${ }^{a, b} \quad$ Amke R. Hesse ${ }^{a, b} \quad$ Aline Jatho $^{a} \quad$ Sabine Krulla \\ Marion Hölschera Sabine Vogel ${ }^{a} \quad$ Dörthe M. Katschinskia,b
}

anstitute of Cardiovascular Physiology, University Medical Center Göttingen, Göttingen, ${ }^{\mathrm{b}} \mathrm{DZHK}$ (German Center for Cardiovascular Research), partner site Göttingen, Göttingen, Germany

\section{Key Words}

Hypoxia $\bullet$ Hypoxia-inducible factor $\bullet$ Ischemia $\bullet$ Heart $•$ PHD3

\begin{abstract}
Aims: The prolyl-4-hydroxylase domain (PHD) enzymes are representing novel therapeutic targets for ischemic tissue protection. Whereas the consequences of a knock out of the PHDs have been analyzed in the context of cardioprotection, the implications of PHD overexpression is unknown so far. Methods and Results: We generated cardiomyocyte-specific PHD3 transgenic mice (cPhd3tg). Resting cPhd3tg mice did not show constitutive accumulation of HIF- $1 \alpha$ or HIF- $2 \alpha$ or changes in HIF target gene expression in the heart. Cardiac function was followed up for 14 months in these mice and found to be unchanged. After challenging the cPhd3tg mice with ligation of the left anterior descending artery, HIF-1 $\alpha /-2 \alpha$ accumulation in the left ventricles was blunted. This was associated with a significantly increased infarct size of the cPhd3tg compared to wild type mice. Conclusion: Whereas overexpression of PHD3 in the resting state does not significantly influence cardiac function, it is crucial for the cardiac response to ischemia by affecting HIF $\alpha$ accumulation in the ischemic tissue.
\end{abstract}

Copyright (c) 2015 S. Karger AG, Basel

\section{Introduction}

Hypoxic transcriptional gene expression is mainly driven by the hypoxia-inducible factor-1 (HIF-1) and 2 (HIF-2). Their $\alpha$-subunits are regulated by oxygen-dependent hydroxylation and subsequent ubiquitination [1]. The prolyl-4-hydroxylase domain enzymes

\section{A. Zieseniss and A.R. Hesse contributed equally to this work}




\section{Cellular Physiology Cell Physiol Biochem 2015;36:843-851 \\ \begin{tabular}{l|l} 
DOI: 10.1159/000430260 & (c) 2015 S. Karger AG, Basel
\end{tabular} \\ and Biochemistry Published online: May 27, 2015 www.karger.com/cpb}

(PHD) 1-3 and the von Hippel Lindau protein are responsible for this regulation [2, 3]. Based on the fact that the $\mathrm{K}_{\mathrm{m}}$ values of the PHDs for oxygen are higher than the concentrations generally present in normoxic tissues in vivo, these enzymes can efficiently function as biological oxygen sensors. [4] HIF-1 $\alpha$ plays an important role in cardioprotection induced by ischemic preconditioning $[5,6]$. Thus, induction of the HIF response via inhibition of the PHDs may provide a novel therapeutic strategy in the treatment of ischemic cardioprotection [7]. Studies employing a cardiomyocyte-specific PHD2 knock out mouse line, in which stabilization of HIF-1 $\alpha$ in the pre-ischemic heart can be detected, have demonstrated that these mice had a smaller area of necrosis and area at risk $6 \mathrm{~h}$ after permanent ligation of the left anterior descending (LAD) artery than the control mice. [8] Cardiac tissue protection was likewise observed in hypomorph PHD2 mice, in which the expression level of PHD2 in the heart is reduced to $8 \%$ compared to wild-type (wt) mice $[9,10]$.

Although having overlapping functions with PHD1 and PHD2 in the regulation of HIF $\alpha$, PHD3 differs markedly from the two other isoforms [11]. PHD3 expression is relatively low in normoxia, but highly inducible in hypoxia in various cell models and tissues including the heart [12]. PHD2 is the main regulator of controlling HIF $\alpha$ in normoxia, as inactivation of PHD2 alone leads to stabilization of HIF $\alpha$ in vitro and in vivo whereas PHD3 is especially important for balancing the hypoxic response based on its strong induction after oxygen deprivation $[13,14]$. Despite these differential functions of PHD2 and PHD3 in regulating $\mathrm{HIF} \alpha$, PHD3 knock out mice subjected to LAD ligation showed similar to PHD2 knock out mice improved cardiac functions compared to wild type mice [15]. In addition to its role in the hypoxic response, PHD3 has been associated with additional functions, which may involve HIF-independent but hypoxia-sensitive signaling, that mostly relate to apoptotic pathways. Besides in myeloid and neuronal cells, this has also been demonstrated in embryonic rat heart-derived H9c2 cells [16-18]. Moreover, upregulated PHD3 expression has been found in ageing human and murine hearts as well as in diabetic rat hearts $[12,19]$. It is tempting to speculate that the elevated levels of PHD3 are functionally impacting heart function, however this can't be deduced from the present correlative studies. To analyze if upregulated levels of PHD3 affect myocardial function and the response of the heart to ischemia we generated cardiomyocyte-specific transgenic mice ( $\mathrm{cPhd} 3 \mathrm{tg}$ ) and analyzed the consequences of the transgene under resting conditions and after LAD ligation.

\section{Materials and Methods}

Mice

For the generation of cardiomyocyte-specific PHD3 transgenic mice (cPhd3tg) the pBSIISK- $\alpha$ MHCPHD3 vector was constructed by subcloning the human PHD3 cDNA into the SalI/HindIII cloning site of the pBSKIISK- $\alpha$ MHC vector [20]. After digestion with KpnI the fragment carrying the $\alpha$ MHC promoter and PHD3 cDNA was used for microinjection into C57BL/6 zygotes. For animal experimentation, male mice were used.

\section{Animal experimentation and echocardiography}

Animal experimentations were performed with 8-12 week old cPhd3tg mice and the respective littermate wt control mice. All protocols regarding animal experimentation were conducted according to the German animal protection law and approved by the responsible governmental authority (Niedersächsisches Landesamt für Verbraucherschutz und Lebensmittelsicherheit; animal experimentation number 33.942502-04-10/0069). LAD ligations were performed by an investigator, who was blinded regarding the genotypes of the mice as described previously [8]. The measurement of infarct size was performed by an additional investigator, who was likewise blinded.

For ligation of the LAD mice were anesthetized using 1.5\% isoflurane (Forene, Abbott), applied by a blunt intubation cannula (intubation cannula, stainless steel with Y-adapter, 1.2-mm outer diameter, 30-mm length; Hugo Sachs Elektronik, Harvard Apparatus $\mathrm{GmbH}$ ) connected to a mechanical ventilator (MiniVent; Hugo Sachs Elektronik, Harvard Apparatus GmbH). Anesthesia was considered adequate when the animal did not respond to external stimuli and did not show the palpebral reflex. Pain management was controlled by intraperitoneal injection of $0.06 \mathrm{mg} / \mathrm{kg}$ body weight (BW) buprenorphine $1 \mathrm{~h}$ before the surgery and 


\section{Cellular Physiology Cell Physiol Biochem 2015;36:843-851 \begin{tabular}{c|l}
\hline DOI: 10.1159/000430260 & (c) 2015 S. Karger AG, Basel
\end{tabular} \begin{tabular}{l|l} 
and Biochemistry Published online: May 27, 2015 & www.karger.com/cpb
\end{tabular} \\ Zieseniss et al.: PHD3 and Myocardial Infarction}

daily treatment with $1.33 \mathrm{mg} / \mathrm{ml}$ metamizole in the drinking water starting 2 days before the surgery.

Echocardiography and measurement of left ventricular end systolic diameter (LVESD), left ventricular end diastolic diameter (LVEDD) and fractional shortening (FS) were performed as described in [21]. In brief mice were anesthetized using 1\% isoflurane (Forene, Abbott) and two-dimensional images and M-mode tracings were recorded from the parasternal long axis view at midpapillary level (Vevo $660^{\text {TM }}$, VS-0 M-VE660 version 3.1, Visual Sonics). FS of the left ventricle was defined as the LVEDD minus LVESD divided by the LVEDD. FS was used as marker for cardiac contractile function.

\section{Measurement of infarct size}

Six hours after LAD ligation the mice were given heparin (250 IU), anesthetized, and the hearts were excised. Myocardial infarct size was determined by using Evans blue/TTC (2,3,5-triphenyltetrazolium chloride). Briefly, the ascending aorta was cannulated with a 20 -gauge tubing adapter, and $1 \%$ Evans blue was perfused into the aorta and coronary arteries to delineate the total "area at risk" (AAR). The Evans blue dye was uniformly distributed to those areas of the myocardium, which were well perfused; hence, the area of the myocardium that was not stained with Evans blue was defined as the total AAR. The left ventricle was separated from the rest of the heart and sectioned into three transverse slices. Sections were incubated in $2 \%$ TTC for 20 min at $37^{\circ} \mathrm{C}$ to identify viable tissue, which will stain red. Infarct quantification was performed on digital photographs (SMZ 1500, Nikon, Tokyo, Japan) using ImageJ (NIH, Bethessda, MD). Area of necrosis (AON) and AAR were determined as the average percent area per slice and were then related to individual slice weight. Myocardial infarct size was calculated as AON/total AAR).

\section{Protein extraction and immunoblot analysis}

Heart tissue was rapidly homogenized in a buffer containing $4 \mathrm{M}$ Urea, $140 \mathrm{mM}$ Tris (pH 6.8), 1\% SDS, 2\% NP-40 and protease inhibitors (Roche). Protein concentrations were quantified (Bio-Rad, DC Protein Assay). For immunoblot analysis protein samples were resolved by SDS-PAGE and transferred onto nitrocellulose membranes (Amersham Biosciences) by semi-dry blotting (PeqLab). Primary antibodies used were: anti-Calsequestrin (Dianova, ABR-01164), anti-GAPDH (Cell Signaling, 2118), anti-HIF-1 $\alpha$ (Novus, NB100-479), anti-HIF-2 $\alpha$ (R\&D, AF2997), anti-PHD2 (Novus, 100-2219), anti-PHD3 (Novus, NB100-303) and anti-Vinculin (Sigma, hVin-1, V9264).

For detection of immunocomplexes horseradish peroxidase-conjugated secondary mouse anti-goat, goat anti-rabbit or goat anti-mouse antibodies (Santa Cruz Biotechnology) were used and membranes were incubated with $100 \mathrm{mM}$ Tris- $\mathrm{HCl}$ ( $\mathrm{pH} 8.5$ ), $2.65 \mathrm{mM} \mathrm{H}_{2} \mathrm{O}_{2}, 0.45 \mathrm{mM}$ luminol, and $0.625 \mathrm{mM}$ coumaric acid for $1 \mathrm{~min}$. Western Blot signals were quantified using ImageJ.

\section{qRT-PCR analysis}

After phenol/chloroform RNA extraction, reverse transcription (RT) was performed with $2 \mu \mathrm{g}$ of RNA and a first strand cDNA synthesis kit (Fermentas, St. Leon-Rot). mRNA levels were quantified by using $1 \mu \mathrm{l}$ of the cDNA reaction and the SyBR Green qPCR reaction kit (Clontech, Paris, France) in combination with the MX3000P light cycler (Stratagene). Initial template concentration of each sample was normalized to the house keeping gene $\mathrm{mS} 12$ and calculated by the $\Delta \Delta \mathrm{CT}$ values. Primers were as follows:

BCl-2 forward 5'-CTG ACG CCC TTC ACC GCG AG-3', BCl-2 reverse 5'- AAA GGC ATC CCA GCC TCC GT-3'; Bnip3 forward 5'- GTC CAG TGT CGC CTG GCC TC-3', Bnip3 reverse 5'-TGG GAG CG A GGT GGG CTG TC-3'; GADD153 forward 5'-ACA GCC GGA A CCT GAG GAG AGA-3', GADD153 reverse 5'-ACT CAG CTG CCA TGA CTG CAC G-3'; Glut-1 forward 5' - TGG CCT TGC TGG AAC GGC TG-3', Glut-1 reverse $5^{\prime}$-TCC TTG GGC TGC AGG GAG CA-3'; mS12 forward, 5'- GAA GCT GCC AAG GCC TTA GA-3', mS12 reverse 5' - AAC TGC A AC CAA CCA CCT TC-3'; Pfkl forward 5'-ACG AGG CCA TCC AG CTC CGT-3', Pfkl reverse 5'-TGG GGC TTG GGC AGT GTC CT-3'; PDK-1 forward 5'-GTT CAC G TCA CGC TGG GCG A-3', PDK-1 reverse 5'-CCA GGC GTC CCA TGT GCG TT-3'; PHD1 forward 5'-GCT AGG CTG AGG GAG GAA GT-3', PHD1 reverse 5'-TCT ACC CAG GCA ATC TGG TC-3'; PHD2 forward 5' - TTG CTG ACA TTG AAC CCA AA-3', PHD2 reverse 5'-GGC AAC TGA GAG GCT GTA GG3'; PHD3 forward 5'-GGC CGC TGT ATC ACC TGT A T-3'; PHD3 reverse 5'-TTC TGC CCT TTC TTC AGC AT-3'.

Histological analysis

For Trichrome staining heart tissue was fixed in $4 \%$ paraformaldehyde in phosphate buffered saline (PBS) at $4^{\circ} \mathrm{C}$ for 24 hours and embedded in paraffin before sectioning. 


\section{Cellular Physiology Cell Physiol Biochem 2015;36:843-851 \begin{tabular}{l|l|}
\hline DOI: 10.1159/000430260 & (c) 2015 S. Karger AG, Basel
\end{tabular} \begin{tabular}{l|l} 
and Biochemistry Published online: May 27, 2015 & www.karger.com/cpb \\
\hline
\end{tabular}

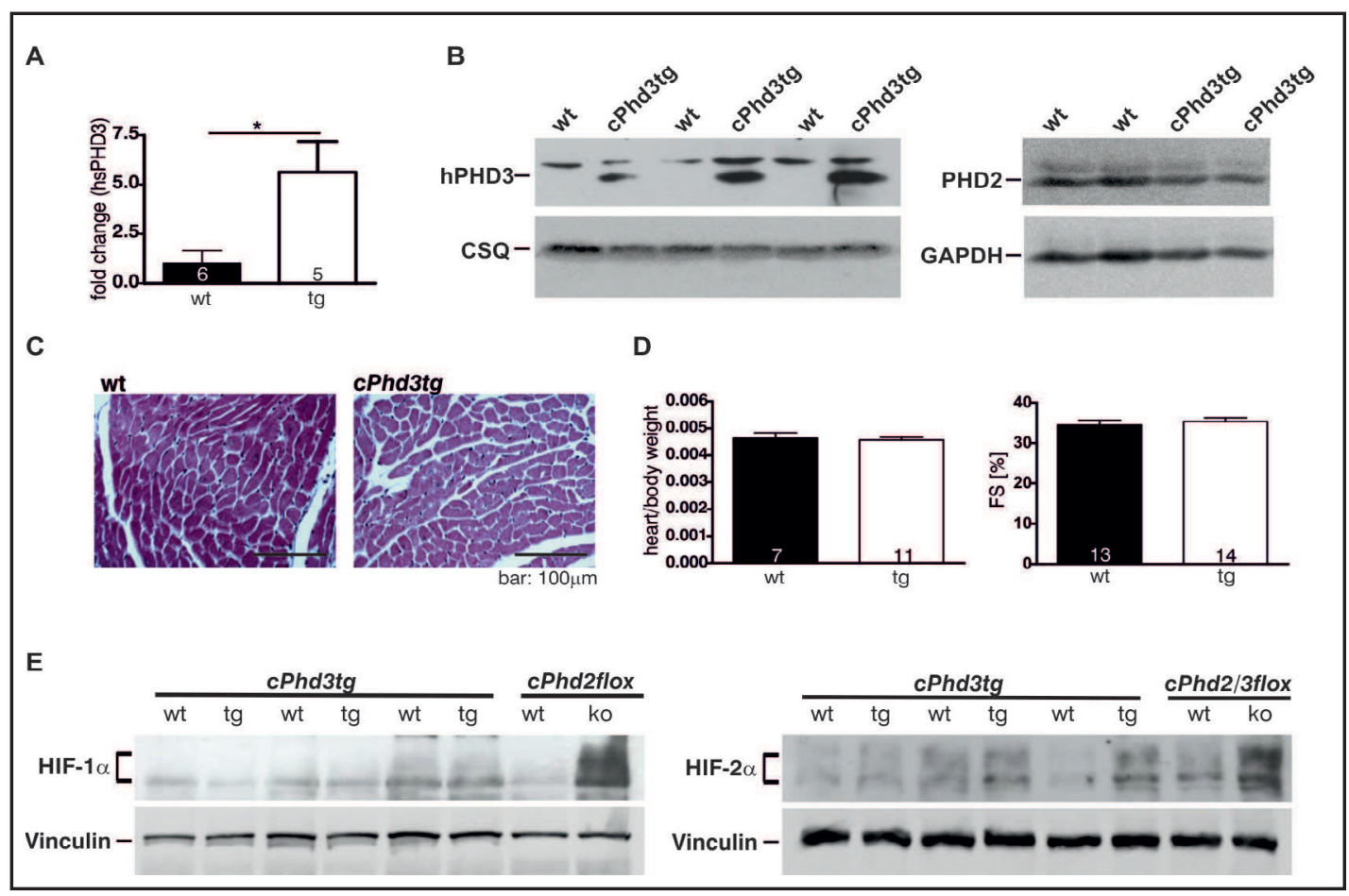

Fig. 1. Overexpression of PHD3 does not affect HIF- $1 \alpha$ and HIF- $2 \alpha$ stabilization in the hearts of resting mice. Left ventricles of $c P h d 3 \mathrm{tg}(\mathrm{tg})$ mice and the respective wild type (wt) animals were analyzed for (A) PHD3 RNA levels by qRT-PCR, (B) PHD2 and PHD3 protein levels by Western blot or (C) histology by Trichrome staining. (D) Heart to body weight ratio and fractional shortening (FS) of $c$ Phd3tg and wt mice. (E) Left ventricles of $c P h d 3 \mathrm{tg}$ mice and the respective wt animals were analyzed for HIF- $1 \alpha$ and HIF- $2 \alpha$ protein levels. As positive controls for the HIF- $1 \alpha$ and HIF- $2 \alpha$ Western blots protein extracts derived from cardiomyocytespecific PHD2 or PHD2/3 knock out mice $\left(c P h d 2^{\text {flox }}\right.$ and $\left.c P h d 2 / 3^{\text {flox }}\right)$ were included, respectively. Vinculin, Calsequestrin (CSQ) and GAPDH were included as protein loading controls. Numbers in the bars represent the number of animals analyzed, shown are mean \pm SEM. ${ }^{*} \mathrm{p}<0.05$. Western blots are representative of at least three independent experiments.

\section{Statistical analysis}

Data were analyzed by 2-tailed Student's $t$ test and presented as mean \pm SEM. A $p$ value less than 0.05 was considered statistically significant. The number of samples analysed in each experiment is indicated in the Figure legends.

\section{Results}

Cardiomyocyte-specific overexpression of PHD3

For inducing a cardiomyocyte-specific overexpression of PHD3 we generated transgenic mice, which express human PHD3 under the control of the $\alpha \mathrm{MHC}$ promoter. qRT-PCR analysis and Western blot analyses from ventricles of $c P h d 3 t g$ and littermate wt control mice verified a successful increase of PHD3 RNA and protein levels without a concomitant increase of PHD2 (Fig. 1A and B). Histological assessment of the hearts revealed no gross abnormalities in the $c$ Phd3tg mice (Fig. 1C). Heart weight and heart function as determined by echocardiography in $c P h d 3 \mathrm{tg}$ mice were found to be not different compared to littermate wt mice (Fig. 1D). Most interestingly both, HIF-1 $\alpha$ and HIF-2 $\alpha$ protein levels were found unchanged in the hearts of $c P h d 3 \mathrm{tg}$ mice (Fig. 1E). As a positive control for the successful detection of HIF- $1 \alpha$ and HIF- $2 \alpha$ we analyzed hearts of cardiomyocyte-specific PHD2/3 knock out mice in the same immunoblot experiments since we have shown previously that a knock out of PHD2 and PHD3 in the heart results in HIF $\alpha$ stabilization [8]. 


\section{Cellular Physiology Cell Physiol Biochem 2015;36:843-851 \begin{tabular}{l|l}
\hline DOI: 10.1159/000430260 & O 2015 S. Karger AG, Basel
\end{tabular} and Biochemistry Published online: May 27, 2015 www.karger.com/cpb

Fig. 2. RNA expression profile of resting cPhd3tg mice. RNA was extracted from left ventricles of cPhd3tg mice and the respective wild type (wt) control animals and analyzed by qRT-PCR. ( $\mathrm{n}=6$ per group).

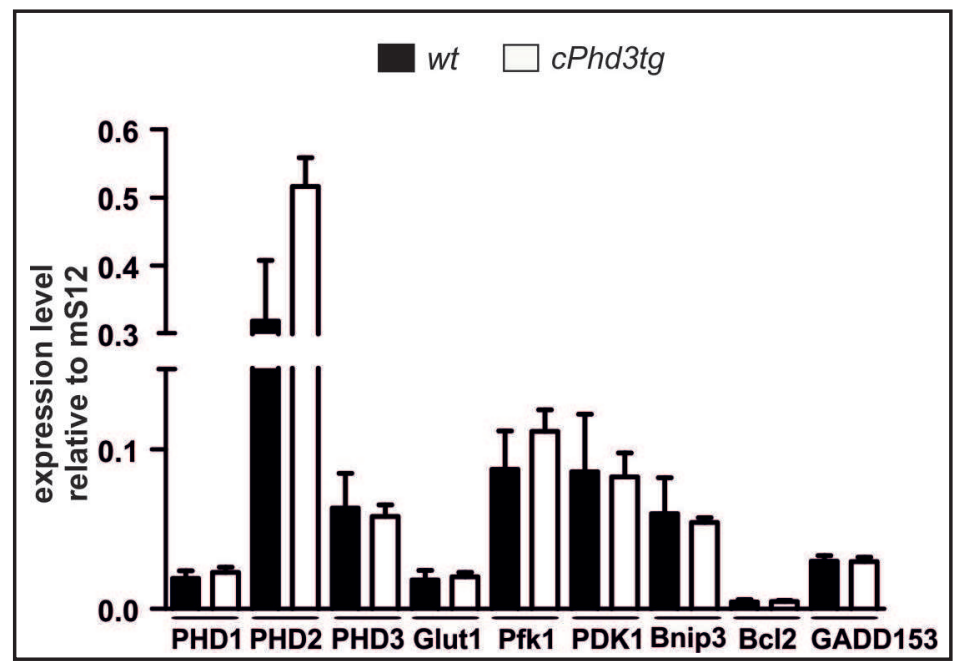

Fig. 3. Overexpression of PHD3 in the heart does not alter cardiac function over time. $c P h d 3 \mathrm{tg}$ mice (n $=6)$ and their wild type (wt) controls $(n=6)$ were analyzed for fractional shortening (FS), posterior wall thickness (PWTh) and anterior wall thickness (AWTh) over time. Mean \pm SEM.

We analyzed the RNA levels of murine PHD1, PHD2 and PHD3 in the $c$ Phd3tg mice. The endogenous expression of the PHDs was not affected by the transgenic overexpression of human PHD3 (Fig. 2). HIF is a key regulator responsible for the induction of genes that facilitate adaptation and survival of cells and the whole organism in hypoxia [22]. Neither HIF target genes like Glut1, Pfk1 and PDK1 nor the mRNAs of the apoptosis related genes GADD153, Bnip3 or Bcl2 were differentially expressed in the resting $c P h d 3 t g$ mice.

To analyse, if over time PHD3 overexpression affects cardiac function, we followed up cPhd3tg and wt mice over a period of 14 months. FS, anterior (AWTh) and posterior wall thickness (PWTh) were determined every other month. Neither the cardiac hypertrophy markers (AWTh and PWth) nor FS, which is indicative for contractile function, were altered in the cPhd3tg mice (Fig. 3).

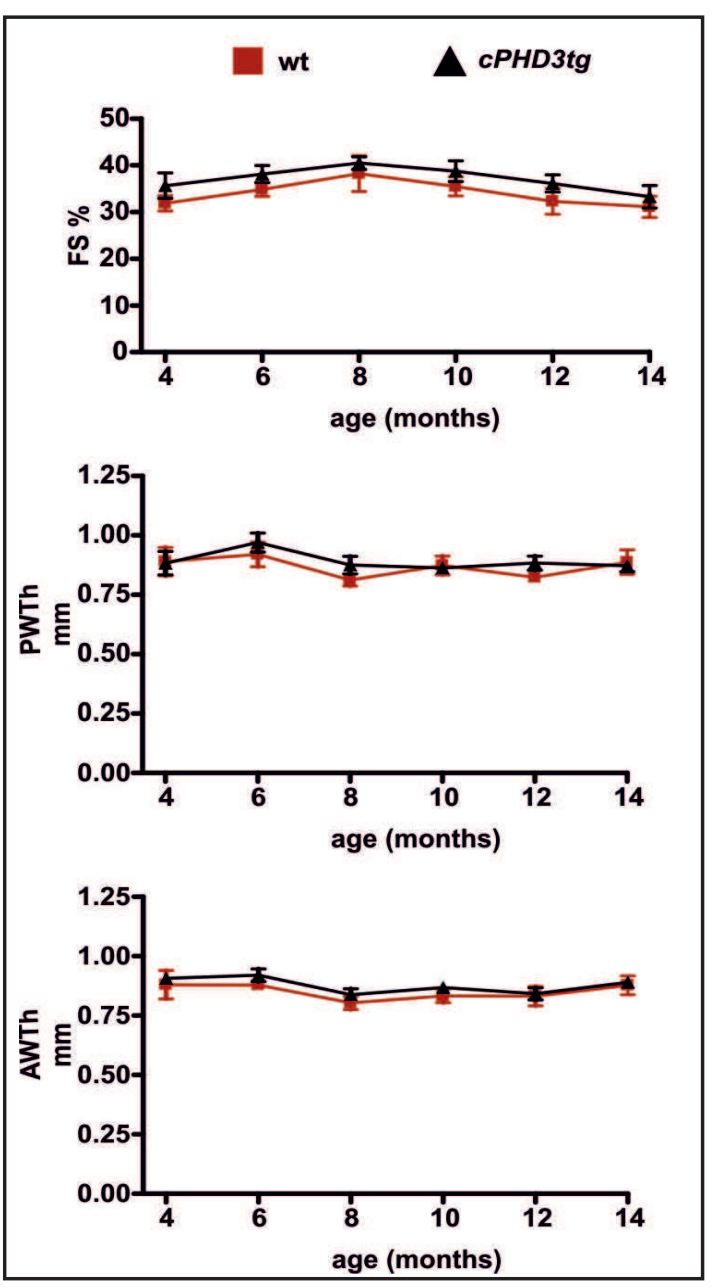

Gain of PHD3 affects HIF in the ischemic myocardium and myocardial infarct size

Data from several groups support the idea that HIF $\alpha$ stabilization by conditional overexpression of HIF-1 $\alpha$ or knock out of PHD2 is beneficial in the setting of acute myocardial ischemia $[8,23]$. In infarcted hearts of wt mice we found increased protein levels of HIF-1 $\alpha$ and HIF- $\alpha$ after LAD ligation (Fig. 4A and B), which are initiating the endogenous adaptive transcriptional response towards the ischemic insult. The development of the $c P h d 3 \mathrm{tg}$ mice allowed us to analyse the consequences of a specific gain of PHD3 for this ischemic HIF $\alpha$ 


\section{Cellular Physiology Cell Physiol Biochem 2015;36:843-851 \begin{tabular}{l|l} 
DOI: 10.1159/000430260 & O 2015 S. Karger AG, Basel
\end{tabular} and Biochemistry Published online: May 27, $2015 \quad$ www.karger.com/cpb

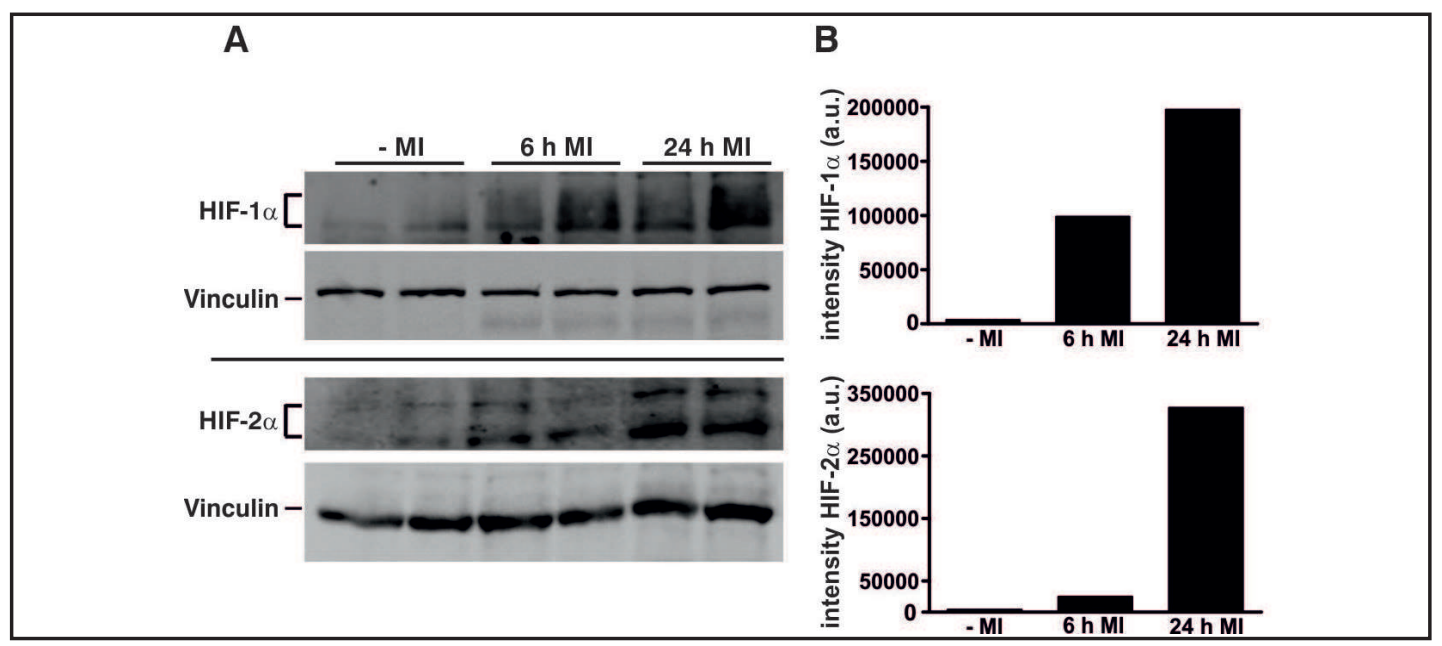

Fig. 4. HIF-1 $\alpha$ and HIF- $2 \alpha$ are stabilized in the heart after myocardial infarction. Wild type mice underwent myocardial infarction (MI) induced by LAD ligation. At the indicated time points left ventricles were excised and analyzed for HIF-1 $\alpha$ and HIF-2 $\alpha$ protein levels by Western blots (A). Vinculin was included as protein loading control. (B) Quantification of the HIF-1 $\alpha$ and HIF-2 $\alpha$ signals of the Western blots in A.

response and the functional outcome after myocardial infarction. Gain of PHD3 restrained the HIF- $1 \alpha$ and HIF- $2 \alpha$ stabilization after myocardial infarction (Fig. 5A and B). This was associated with a significantly increased myocardial infarct size (Fig. 5C and D). As in the untreated animals, no compensatory change of PHD2 in the hearts after LAD-ligation was detectable indicating that altered HIF $\alpha$ levels were due to transgenic PHD3 expression (Fig. $5 \mathrm{E})$.

Our data demonstrate that gain of PHD3 does not affect cardiac function in resting animals, however results in instability of the self-regulating hypoxic loop with the result of a diminished adaptation of the heart to ischemia.

\section{Discussion}

In the present study, we analyzed the consequences of transgenic overexpression of PHD3 in the heart in resting animals and after MI. Resting cardiac function was unchanged even in older $c P h d 3 \mathrm{tg}$ animals. Cardiac overexpression of other components of the cellular oxygen sensing system, i.e. HIF- $1 \alpha$, HIF- $2 \alpha$ and pVHL or the combined knock out of PHD2 and PHD3 are resulting in the development of cardiomyopathies [24-26]. These mouse models have constitutively high levels of HIF $\alpha$ in common. In contrast, in resting cPhd3tg mice we did not find any changes regarding HIF- $1 \alpha$ and HIF- $2 \alpha$ protein levels or HIF target gene expression at the RNA level in the heart. This indicates that high levels of PHD3 per se do not impair cardiac function.

Different from PHD1 and PHD2, PHD3 has been associated with other non-HIF functions including regulation of cell survival decisions [17, 27, 28]. Regarding the HIF system PHD3 is considered to be the molecular fine-tuning tool to control the HIF $\alpha$ response in hypoxia $[14,29]$. HIF-1 is a critical mediator for ischemia-preconditioning-induced cardioprotection. This has been shown in haplodeficient HIF- $1 \alpha$ mice, by using a HIF-1 $\alpha$ siRNA approach or stabilization of myocardial HIF- $1 \alpha$ by pharmacological inhibition of the PHDs [5, 6, 30]. In contrast to the resting $c P h d 3 t g$ mice PHD3 overexpression affected HIF $\alpha$ stabilization and the tissue response to ischemia in mice challenged by LAD ligation. Myocardial infarct size was significantly increased in the $c P h d 3 t g$ mice, which was associated with a diminished accumulation of HIF- $1 \alpha$ and HIF-2 $\alpha$. PHD3 is strongly inducible by hypoxia itself [11]. Our group has previously demonstrated an augmented expression of cardiac PHD3 expression with increasing age [12]. The aging heart is more sensitive to ischemic injury [31]. Moreover, 


\section{Cellular Physiology Cell Physiol Biochem 2015;36:843-851 \begin{tabular}{l|l}
\hline DOI: 10.1159/000430260 & O 2015 S. Karger AG, Basel
\end{tabular} and Biochemistry Published online: May 27, 2015 www.karger.com/cpb}

Fig. 5. PHD3 overexpression alters the HIF $\alpha$ response and outcome after myocardial infarction. $c P h$ d3tg and wild type (wt) mice underwent myocardial infarction (MI) induced by LAD ligation. 6 hours after the intervention, HIF- $1 \alpha$ and HIF- $2 \alpha$ protein levels were determined by Western blots (A) and quantified (B). As a control for the resting condition without MI, a representative protein extract of one wt and one cPhdtg mouse were loaded. Vinculin was included as protein loading control. (C) Total infarct sizes were analyzed by Evans Blue perfusion and TTC stainings $6 \mathrm{hrs}$ after MI. (D) Representative infarct size staining are shown. The area of necrosis (AON) is framed by the grey lining. (E) PHD2 RNA levels were quantified in wt and cPhd2tg mice under resting conditions and after MI. Numbers in the bars represent the number of animals analyzed, shown are mean \pm SEM. ${ }^{*} p<0.05$. Western blots are representative of at least three independent experiments.

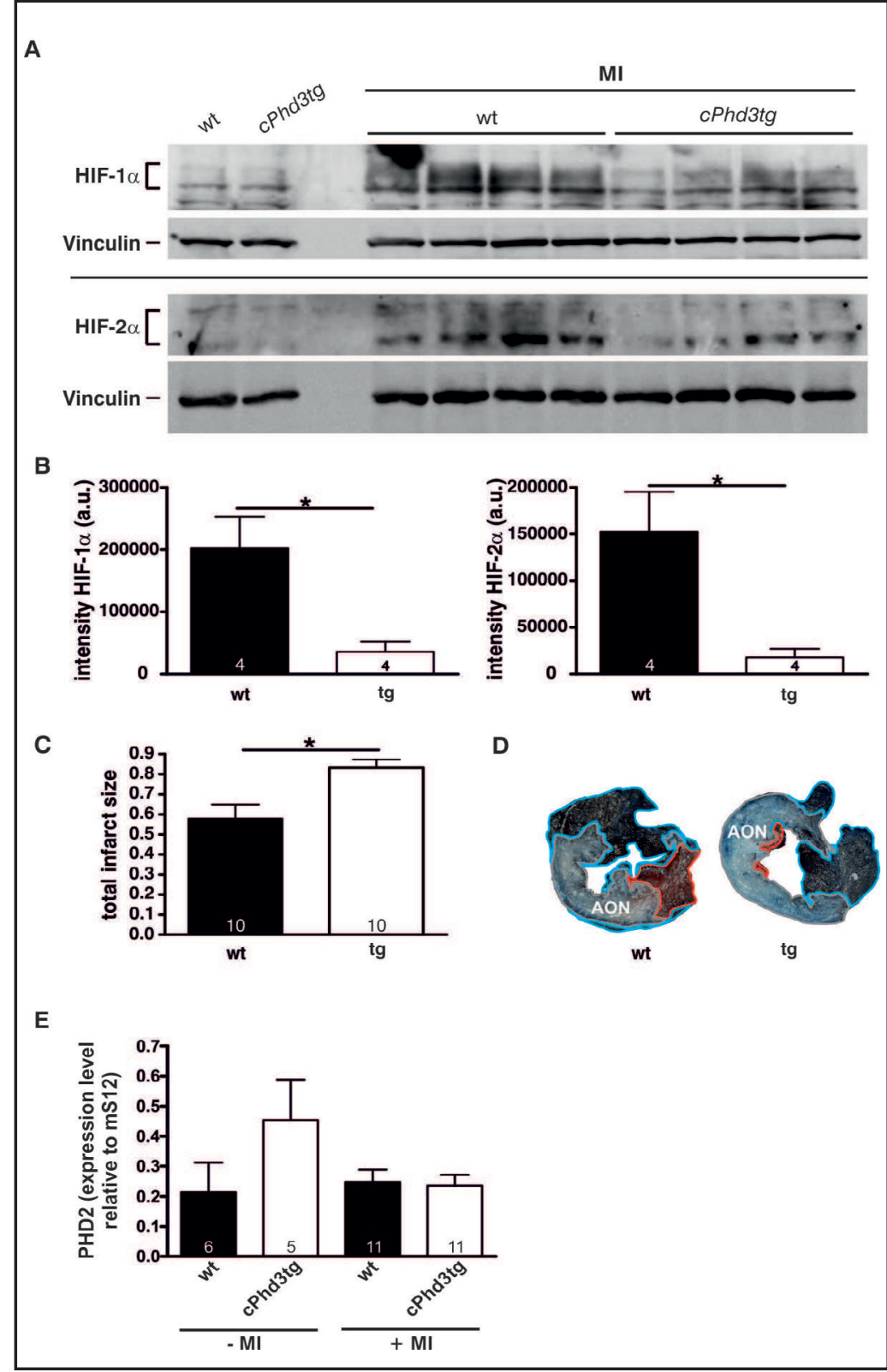

Xia et al. reported recently increased PHD3 levels in diabetic rat hearts, which develop a dilated cardiomyopathy [19]. Thus, one might speculate that the altered expression of PHD3 might be at least in part associated to the described significant age-differences in clinical characteristics in elderly patients with acute myocardial infarction or with the consequences of hyperglycemia-induced cardiomyopathy [32].

PHD inhibitors that activate HIF are an attractive therapeutic option for minimizing tissue damage from myocardial ischemia. Several PHD inhibitory drugs are in development to test their protective effect from an ischemic insult [7]. There are however several caveats to be considered including tissue specificity, therapeutic time window, PHD isoform effects etc. [33]. We have recently demonstrated that pre- as well as post-conditional application of a PHD inhibitor protects the heart from an ischemic insult [34]. PHD3 is upregulated in hypoxic tissue and is most likely limiting the HIF $\alpha$ response. This assumption is in line with unrestricted high HIF $\alpha$ levels in mice, in which PHD2 in combination with PHD3 is knocked out [25]. Therefore inhibition of the increased PHD3 activity in hypoxic tissue might be indeed beneficial for tissue reconstitution. 


\section{Cellular Physiology Cell Physiol Biochem 2015;36:843-851 \begin{tabular}{c|c}
\hline DOI: 10.1159/000430260 & (c) 2015 S. Karger AG, Basel
\end{tabular} \begin{tabular}{l|l} 
and Biochemistry Published online: May 27, 2015 & www.karger.com/cpb
\end{tabular} \\ Zieseniss et al.: PHD3 and Myocardial Infarction}

Taken together, as a consequence of PHD3 overexpression there is no change in cardiac function in resting mice. The ischemic response of the heart however is impaired. These data underscore the physiological roles of the PHD enzymes and shed new light on the function of PHD3 in the heart. From these data one could deduce that strong expression of PHD3 in the heart should be prevented since it might limit the response of the tissue towards an ischemic stimulus.

\section{Acknowledgements}

The work was supported by the Deutsche Zentrum für Herz Kreislaufforschung (DZHK).

\section{Disclosure Statement}

None declared

\section{References}

1 Kaelin WG Jr, Ratcliffe PJ: Oxygen sensing by metazoans: the central role of the HIF hydroxylase pathway. Mol Cell 2008;30:393-402.

2 Ivan M, Kondo K, Yang H, Kim W, Valiando J, Ohh M, Salic A, Asara JM, Lane WS, Kaelin Jr WG: HIF $\alpha$ targeted for VHL-mediated destruction by proline hydroxylation: implications for 02 sensing. Science 2001;292:464-468.

3 Jaakkola P, Mole DR, Tian YM, Wilson MI, Gielbert J, Gaskell SJ, von Kriegsheim A, Hebestreit HF, Mukherji M, Schofield CJ, Maxwell PH, Pugh CW, Ratcliffe PJ: Targeting of HIF- $\alpha$ to the von Hippel-Lindau ubiquitylation complex by 02-regulated prolyl hydroxylation. Science 2001;292:468-472.

4 Hirsilä M, Koivunen P, Gunzler V, Kivirikko KI, Myllyharju J: Characterization of the human prolyl 4-hydroxylases that modify the hypoxia-inducible factor. J Biol Chem 2003;278:30772-30780.

5 Cai Z, Zhong H, Bosch-Marce M, Fox-Talbot K, Wang L, Wei C, Trush MA, Semenza GL: Complete loss of ischaemic preconditioning-induced cardioprotection in mice with partial deficiency of HIF-1 $\alpha$. Cardiovasc Res 2008;77:463-470.

6 Eckle T, Kohler D, Lehmann R, El Kasmi K, Eltzschig HK: Hypoxia-inducible factor-1 is central to cardioprotection: a new paradigm for ischemic preconditioning. Circulation 2008;118:166-175.

7 Katschinski DM: In vivo functions of the prolyl-4-hydroxylase domain oxygen sensors: direct route to the treatment of anaemia and the protection of ischaemic tissues. Acta Physiol (Oxf) 2009;195:407-414.

8 Hölscher M, Silter M, Krull S, von Ahlen M, Hesse A, Schwartz P, Wielockx B, Breier G, Katschinski DM, Zieseniss A: Cardiomyocyte-specific prolyl-4-hydroxylase domain 2 knock out protects from acute myocardial ischemic injury. J Biol Chem 2011;286:11185-11194.

9 Hyvarinen J, Hassinen IE, Sormunen R, Maki JM, Kivirikko KI, Koivunen P, Myllyharju J: Hearts of hypoxiainducible factor prolyl 4-hydroxylase-2 hypomorphic mice show protection against acute ischemiareperfusion injury. J Biol Chem 2010;285: 42023-42032.

10 Kerkela R, Karsikas S, Szabo Z, Serpi R, Magga J, Gao E, Alitalo K, Anisimov A, Sormunen R, Pietila I, Vainio L, Koch WJ, Kivirikko KI, Myllyharju J, Koivunen P: Activation of hypoxia response in endothelial cells contributes to ischemic cardioprotection. Mol Cell Biol 2013;33:3321-3329.

11 Jaakkola PM, Rantanen K: The regulation, localization, and functions of oxygen-sensing prolyl hydroxylase PHD3. Biol Chem 2013;394:449-457.

12 Rohrbach S, Simm A, Pregla R, Franke C, Katschinski DM: Age-dependent increase of prolyl-4-hydroxylase domain (PHD) 3 expression in human and mouse heart. Biogerontology 2005;6:165-171.

13 Appelhoff RJ, Tian YM, Raval RR, Turley H, Harris AL, Pugh CW, Ratcliffe PJ, Gleadle JM: Differential function of the prolyl hydroxylases PHD1, PHD2, and PHD3 in the regulation of hypoxia-inducible factor. J Biol Chem 2004;279:38458-38465.

14 Stiehl DP, Wirthner R, Köditz J, Spielmann P, Camenisch G, Wenger RH: Increased prolyl 4-hydroxylase domain proteins compensate for decreased oxygen levels. Evidence for an autoregulatory oxygen-sensing system. J Biol Chem 2006;281:23482-23491. 


\section{Cellular Physiology Cell Physiol Biochem 2015;36:843-851 \begin{tabular}{l|l|l}
\hline DOI: 10.1159/000430260 & ( 2015 S. Karger AG, Basel
\end{tabular} \begin{tabular}{l|l} 
and Biochemistry Published online: May 27, 2015 & www.karger.com/cpb
\end{tabular} \\ Zieseniss et al.: PHD3 and Myocardial Infarction}

15 Oriowo B, Thirunavukkarasu M, Selvaraju V, Adluri RS, Zhan L, Takeda K, Fong GH, Sanchez JA, Maulik $\mathrm{N}$ : Targeted gene deletion of prolyl hydroxylase domain protein 3 triggers angiogenesis and preserves cardiac function by stabilizing hypoxia inducible factor $1 \alpha$ following myocardial infarction. Curr Pharm Des 2014;20:1305-1310.

16 Lee S, Nakamura E, Yang H, Wei W, Linggi MS, Sajan MP, Farese RV, Freeman RS, Carter BD, Kaelin WG Jr, Schlisio S: Neuronal apoptosis linked to EglN3 prolyl hydroxylase and familial pheochromocytoma genes: developmental culling and cancer. Cancer Cell 2005;8:155-167.

17 Swain L, Wottawa M, Hillemann A, Beneke A, Odagiri H, Terada K, Endo M, Oike Y, Farhat K, Katschinski DM: Prolyl-4-hydroxylase domain 3 (PHD3) is a critical terminator for cell survival of macrophages under stress conditions. J Leukoc Biol 2014;96:365-375.

18 Bishop T, Gallagher D, Pascual A, Lygate CA, de Bono JP, Nicholls LG, Ortega-Saenz P, Oster H, Wijeyekoon B, Sutherland AI, Grosfeld A, Aragones J, Schneider M, van Geyte K, Teixeira D, Diez-Juan A, Lopez-Barneo J, Channon KM, Maxwell PH, Pugh CW, Davies AM, Carmeliet P, Ratcliffe PJ: Abnormal sympatho-adrenal development and systemic hypotension in PHD3-/- mice. Mol Cell Biol 2008;28:3386-3400.

19 Xia Y, Gong L, Liu H, Luo B, Li B, Li R, Lv M, Pan J, An F: Inhibition of prolyl hydroxylase 3 ameliorates cardiac dysfunction in diabetic cardiomyopathy. Mol Cell Endocrinol 2015:doi:10.1016/j.mce.2015.01.014.

20 Subramaniam A, Jones WK, Gulick J, Wert S, Neumann J, Robbins J: Tissue-specific regulation of the alphamyosin heavy chain gene promoter in transgenic mice. J Biol Chem 1991;266:24613-24620.

21 Silter M, Kogler H, Zieseniss A, Wilting J, Schafer K, Toischer K, Rokita AG, Breves G, Maier LS, Katschinski DM. Impaired Ca2+-handling in HIF-1 $\alpha+$ /- mice as a consequence of pressure overload. Eur J Physiol 2010;459:569-577.

22 Schödel J, Mole DR, Ratcliffe PJ: Pan-genomic binding of hypoxia-inducible transcription factors. Biol Chem 2013;394:507-517.

23 Kido M, Du L, Sullivan CC, Li X, Deutsch R, Jamieson SW, Thistlethwaite PA: Hypoxia-inducible factor $1 \alpha$ reduces infarction and attenuates progression of cardiac dysfunction after myocardial infarction in the mouse. J Am Coll Cardiol 2005;46:2116-2124.

24 Hölscher M, Schäfer K, Krull S, Farhat K, Hesse A, Silter M, Lin Y, Pichler BJ, Thistlethwaite P, El-Armouche A, Maier LS, Katschinski DM, Zieseniss A: Unfavourable consequences of chronic cardiac HIF-1 $\alpha$ stabilization. Cardiovasc Res 2012;94:77-86.

25 Moslehi J, Minamishima YA, Shi J, Neuberg D, Charytan DM, Padera RF, Signoretti S, Liao R, Kaelin WG Jr: Loss of Hypoxia-Inducible Factor Prolyl Hydroxylase Activity in Cardiomyocytes Phenocopies Ischemic Cardiomyopathy. Circulation 2010;122:1004-1016.

26 Lei L, Mason S, Liu D, Huang Y, Marks C, Hickey R, Jovin IS, Pypaert M, Johnson RS, Giordano FJ: Hypoxia inducible factor-dependent degeneration, failure, and malignant transformation of the heart in the absence of the von Hippel-Lindau protein. Mol Cell Biol 2008:28:3790-803.

27 Köditz J, Nesper J, Wottawa M, Stiehl DP, Camenisch G, Franke C, Myllyharju J, Wenger RH, Katschinski DM: Oxygen-dependent ATF-4 stability is mediated by the PHD3 oxygen sensor. Blood 2007;110:3610-3617.

28 Schlisio S, Kenchappa RS, Vredeveld LC, George RE, Stewart R, Greulich H, Shahriari K, Nguyen NV, Pigny P, Dahia PL, Pomeroy SL, Maris JM, Look AT, Meyerson M, Peeper DS, Carter BD, Kaelin WG Jr: The kinesin $\mathrm{KIF} 1 \mathrm{Bb}$ acts downstream from EglN3 to induce apoptosis and is a potential 1p36 tumor suppressor. Genes Dev 2008;22:884-893.

29 Minamishima YA, Moslehi J, Padera RF, Bronson RT, Liao R, Kaelin WG Jr: A feedback loop involving the Phd3 prolyl hydroxylase tunes the mammalian hypoxic response in vivo. Mol Cell Biol 2009;29:5729-5741.

30 Cai Z, Luo W, Zhan H, Semenza GL: Hypoxia-inducible factor 1 is required for remote ischemic preconditioning of the heart. Proc Natl Acad Sci 2013;110:17462-17467.

31 Lesnefsky EJ, Moghaddas S, Tandler B, Kerner J, Hoppel CL: Mitochondrial dysfunction in cardiac disease: ischemia--reperfusion, aging, and heart failure. J Mol Cell Cardiol 2001;33:1065-1089.

32 Mehta RH, Rathore SS, Radford MJ, Wang Y, Krumholz HM: Acute myocardial infarction in the elderly: differences by age. J Am Coll Cardiol 2001;38:736-741.

33 Myllyharju J: HIF prolyl 4-hydroxylases and their potential as drug targets. Curr Pharm Des 2009;15:38783885.

34 Vogler M, Zieseniss A, Hesse AR, Levent E, Tiburcy M, Heinze E, Burzlaff N, Schley G, Eckardt KU, Willam C, Katschinski DM: Pre- and post-conditional inhibition of prolyl-4-hydroxylase domain enzymes protects the heart from an ischemic insult. Eur J Physiol 2015; doi 10.1007/s00424-014-1667-z. 